Economics Development Analysis Journal 5 (4) (2016)

\title{
Pengaruh Kondisi Individu terhadap Keputusan Migrasi Sirkuler ke Kota Semarang
}

Hastu Rahma Anggraini ${ }^{1 凶}$, Fafurida ${ }^{2}$

${ }^{1} \mathrm{PT}$. Asuransi Cigna

${ }^{2}$ Jurusan Ekonomi Pembangunan, Fakultas Ekonomi, Universitas Negeri Semarang

\section{Info Artikel}

Sejarah Artikel:

Diterima September

2016

Disetujui Oktober 2016

Dipublikasikan

November 2016

\section{Keywords:}

Migration, Circular, Binary

Logistic Regression

\begin{abstract}
Abstrak
Fenomena migrasi sangat mewarnai di beberapa negara berkembang, termasuk di berbagai daerah di Indonesia. Di Indonesia terutama banyak tenaga kerja yang berasal dari daerah pedesaan mengalir ke daerah perkotaan, Salah satunya dari Kabupaten Kendal. Penelitian ini bertujuan untuk mengetahui faktor-faktor yang berpengaruh terhadap keputusan migrasi sirkuler yang antara lain meliputi jenis kelamin, usia, status perkawinan, tingkat pendidikan dan pendapatan. Populasi dalam penelitian ini adalah tenaga kerja kabupaten Kendal yang bekerja di Kota Semarang dan menjadi migrasi sirkuler yang jumlahnya 1.135 jiwa Tidak semua tenaga kerja dalam populasi menjadi objek dalam penelitian ini karena jumlahnya sulit untuk diketahui. Pengambilan sampel dilakukan dengan metode Snowball sampling dalam hal ini sampel adalah tenaga kerja di sektor formal yang bekerja di Kota Semarang dan menjadi migrasi sirkuler yang berjumlah 92 responden. Berdasarkan hasil penelitian menunjukkan bahwa Jenis kelamin berpengaruh positif dan signifikan terhadap migrasi sirkuler, usia berpengaruh positif dan tidak signifikan terhadap migrasi sirkuler, status perkawinan berpengaruh negatif dan tidak signifikan terhadap migrasi sirkuler, tingkat pendidikan berpengaruh positif dan signifikan terhadap migrasi sirkuler, pendapatan berpengaruh negatif dan signifikan terhadap migrasi sirkuler.
\end{abstract}

(C) 2016 Universitas Negeri Semarang

Alamat korespondensi: ISSN 2252-6765

Jalan H.R. Rasuna Said Kav, Kuningan Tim.,

Kota Jakarta Selatan, Daerah Khusus Ibukota Jakarta 12950

E-mail: hasturahma.anggraini@gmail.com 


\section{PENDAHULUAN}

Perbedaan pendapatan antara pedesaan dan perkotaan serta disparitas kesempatan ekonomi telah mendorong seseorang mencari pekerjaan di kota yang upahnya lebih tinggi. Upah yang diharapkan di perkotaan masih melampaui pendapatan di desa. Pembangunan ekonomi yang lebih menguntungkan daerah perkotaan dalam kebanyakan perencanaan Negara-negara belum berkembang pada tahun 1950-an dan tahun 1960-an, ditambah dengan kurangnya perhatian pada sektor pertanian dan pedesaan secara relatif, telah menciptakan kondisi kondisi dan distorsi harga dan insentif ekonomi, yang menyebabkan terbatasnya lapangan pekerjaan di pedesaan (Todaro, 2000)

Peningkatan jumlah penduduk ternyata sejalan dengan meningkatnya angka pertumbuhan angkatan kerja yang semakin lama semakin bertambah banyak namun tidak disejalan dengan penciptaan lapangan kerja yang memadai. Dengan demikian terdapat suatu ketimpangan antara lapangan pekerjaan yang tersedia dengan banyaknya jumlah tenaga kerja yang ada. Mau tidak mau dengan kondisi tersebut menyebabkan banyak calon tenaga kerja baru sulit mendapatkan pekerjaan baik di sektor formal maupun di sektor informal karena persaingan yang sangat banyak.

Adanya perbedaan yang berarti antara desa dan kota dari segi ekonomi dan kesempatan kerja, menyebabkan adanya migrasi dari desa ke kota. Makin tinggi perbedaan tersebut makin banyak penduduk yang melaksanakan migrasi. Alasan utama mereka melaksanakan migrasi ialah alasan ekonomi, sosial dan kejiwaan. (Lee, 1995). Besarnya pertambahan penduduk di pedesaan akan berakibat semakin menyempitnya lapangan kerja di daerah tersebut. Pada akhirnya akan memotivasi penduduk pedesaan itu sendiri untuk melakukan migrasi, dengan harapan akan dapat lebih mencukupi kebutuhan keluarga. Kondisi sosial ekonomi suatu penduduk seperti rendahnya tingkat pendapatan dan belum tersedianya fasilitas pembangunan. Penduduk di kawasan pinggiran akan memilih untuk bekerja di kota sebagai sirkuler dengan harapan memberikan kesempatan kerja yang lebih layak serta penghasilan yang lebih tinggi.

Semakin meningkatnya kebutuhan tiap individu dalam satu rumah tangga, peningkatan harga beli berbagai barang serta pengaruh kehidupan sosial dalam suatu lingkungan pada akhirnya akan menuntut individu untuk mendapatkan penghasilan yang tinggi untuk memenuhi segala macam kebutuhan terutama yang bersifat mendesak.

Seseorang akan mengunakan prinsip ekonomi dimana mereka akan menentukan pilihan yang akan memberi manfaat yang maksimal dengan biaya yang minimum. Akan tetapi apa yang dilakukan para penduduk yang melakukan sirkuler yang mencari nafkah di kota besar seperti Semarang mengeluarkan biaya yang tidak sedikit, dan akan menambah biaya pengeluaran orang yang melakukan sirkuler. Biaya yang dikeluarkan untuk melakukan sirkuler akan meningkat dan penghasilan berkurang, sehingga akan berdampak terhadap kinerja dan keinginan penduduk untuk melakukan sirkuler.

Berikut merupakan tabel perbandingan UMK kota semarang dengan Kabupaten Kendal yang di jelaskan dalam Tabel 1.1 sebagai berikut:

Tabel 1. Perbandingan UMK Kota Semarang dan Kabupaten Kendal

\begin{tabular}{lll}
\hline Tahun & $\begin{array}{c}\text { UMK Kota } \\
\text { Semarang }\end{array}$ & $\begin{array}{c}\text { UMK Kab } \\
\text { Kendal }\end{array}$ \\
\hline 2011 & $961.323,00$ & $843.750,00$ \\
2012 & $991.500,00$ & $904.500,00$ \\
2013 & $1.209 .100,00$ & $953.100,00$ \\
\hline
\end{tabular}

Sumber : disnakertrans jateng 2014

Berdasarkan Tabel 1 bisa terlihat bahwa selisih angka UMK antara Kota Semarang dengan Kabupaten Kendal tidak terlalu besar, namun penduduk akan tetap memilih untuk mendapatkan pekerjaan dengan penghasilan yang lebih tinggi. Interaksi yang terjadi antara penduduk Kabupaten Kendal dengan Kota Semarang menjadi semakin kuat karena kegiatan tersebut berlangsung setiap hari. Mereka akan menggunakan uang tersebut 
sebagai pemenuhan akan berbagai kebutuhan atau yang sering disebut dengan konsumsi. Konsumsi merupakan suatu kegiatan yang dilakukan manusia untuk memenuhi kebutuhan hidup rumah tangga baik kebutuhan yang konkrit seperti makanan, minuman, dan sebagainya maupun kebutuhan yang tidak konkrit seperti pemenuhan pendidikan dan fasilitas kesehatan.

Kabupaten Kendal merupakan salah satu kabupaten di Jawa Tengah yang memiliki jarak yang dekat dengan Kota Semarang sebagai Ibu Kota Provinsi. Sedikitnya lapangan kerja di Kabupaten Kendal mendorong tenaga kerja untuk menjadi sirkuler ke Kota Semarang. Jarak merupakan faktor utama yang penting dalam mendorong masyarakat untuk melakukan migrasi penduduk, akan tetapi faktor jarak juga tidak berdiri sendiri karena juga dipengaruhi oleh kondisi sosial ekonomi potensial di Kabupaten Kendal serta informasi tentang daerah tujuan, yaitu Kota Semarang. Berikut adalah data pencari kerja Kab. Kendal.

Tabel 2. Pencari Kerja di Kab. Kendal (Berdasarkan Usia) Tahun 2011-2013

\begin{tabular}{llll}
\hline & Laki- & & \\
Tahun & laki & Perempuan & Jumlah \\
\hline 2011 & 632 & 3073 & 3705 \\
2012 & 2381 & 1429 & 3810 \\
2013 & 2381 & 1429 & 3810 \\
\hline
\end{tabular}

Sumber :BPS, 2014

Berdasarkan Tabel 2 data pencari kerja di Kabupaten Kendal dari tahun ke tahun semakin meningkat. Ibu Kota Jawa tengah Kota Semarang yang merupakan salah satu pusat pertumbuhan ekonomi di Jawa Tengah yang menjadikan kota ini menjadi kota dengan pertumbuhan ekonomi yang tinggi. Pertumbuhan ekonomi yang tinggi memicu semakin terbukanya potensi yang ada dan berdampak pada sektor-sektor yang akan membuka kesempatan kerja sehingga akan menarik para migran untuk ke kota, kondisi inilah yang menyebabkan banyak tenaga kerja tertarik melakukan migrasi sirkuler.
Faktor lainnya yang menyebabkan seseorang menjadi sirkuler adalah kondisi sosialekonomi di daerah asal yang tidak memungkinkan untuk memenuhi kebutuhan seseorang, menyebabkan orang tersebut ingin pergi ke daerah lain yang dapat memenuhi kebutuhan tersebut. Sedangkan setiap individu mempunyai kebutuhan yang berbeda, maka penilaian terhadap daerah asal dari masingmasing individu berbeda-beda, sehingga proses pengambilan keputusan untuk pindah (mobilitas) dari masing-masing individu berbeda pula (Mantra, 1992).

Dalam bermigrasi, penduduk lebih tertarik melakukan perpindahan jarak yang dekat atau melakukan migrasi non permanen. Hal ini disebabkan adanya rasa keterikatan penduduk terhadap keluarga, teman maupun kampung halaman yang ditinggalkan. Jarak yang dekat antara Kota Semarang dengan Kabupaten Kendal, dan sedikitnya lapangan kerja di Kabupaten Kendal mendorong tenaga kerja untuk menjadi sirkuler. Namun, penelitian di China menunjukkan bahwa imigran di China kebanyakan memilih menetap daripada sikuler karena telah mendapatkan pekerjaan yang stabil dan pendapatan yang lebih tinggi ( $\mathrm{Hu}$ Feng, 2011). Tabel 1.3 berikut ini memperlihatkan presentase tingkat pengangguran terbuka dan tingkat partisipasi angkatan kerja di Kabupaten Kendal pada tahun 2011-2013.

Tabel 3. TPT dan TPAK menurut Kabupaten di Kabupaten Kendal Tahun 2011-2013

\begin{tabular}{lll}
\hline \multicolumn{1}{c}{ Tahun } & \multicolumn{1}{c}{ TPT } & TPAK \\
\hline 2011 & 5.59 & 71.36 \\
2012 & 6.34 & 72.88 \\
2013 & 6.42 & 72.00
\end{tabular}

Sumber : Data diolah dari Sakernas Agustus 2011-2013

Berdasarkan Tabel 3 menunjukkan bahwa tingkat pengangguran terbuka dari tahun 2011 terus mengalami peningkatan dari 5.59\% pada tahun 2012 hingga $6.42 \%$ pada tahun 2013 . Tingkat partisipasi angkatan kerja dari tahun ke tahun juga terus meningkat dari $71.36 \%$ pada tahun 2011 hingga 72\% pada tahun 2013 . 


\section{METODE PENELITIAN}

Sekaran (2006) menyatakan populasi mengacu pada keseluruhan kelompok orang, kejadian, atau hal minat yang ingin peneliti investigasi. Populasi adalah seluruh kumpulan dari elemen-elemen yang akan dibuat kesimpulan. Sedangkan elemen (unsur) adalah subjek dimana pengukuran akan dilakukan. Besarnya populasi yang akan digunakan dalam suatu penelitian tergantung pada jangkauan kesimpulan yang akan dibuat atau dihasilkan. Populasi dalam penelitian ini adalah tenaga kerja kabupaten Kendal yang bekerja di Kota Semarang dan menjadi migrasi sirkuler yang jumlahnya 1.135 jiwa menurut disnaker Kabupaten Kendal.

Pengambilan sampel dilakukan dengan metode Snowball sampling merupakan salah satu metode dalam pengambilan sample dari suatu populasi. Dimana snowball sampling ini adalah termasuk dalam teknik non-probability sampling (sample dengan probabilitas yang tidak sama). Untuk metode pengambilan sample seperti ini khusus digunakan untuk data-data yang bersifat komunitas dari subjektif responden/sample, atau dengan kata lain objek sample yang kita inginkan sangat langka dan bersifat mengelompok pada suatu Himpunan. Dengan kata lain snowball sampling metode pengambilan sampel dengan secara berantai (multi level).

Metode pengumpulan data yang digunakan dalam penelitian ini adalah dengan melakukan survei langsung ke daerah penelitian dan melakukan wawancara berdasarkan kuesioner yang telah disusun terhadap responden dan secara dokumentasi dengan studi pustaka dari berbagai literatur atau buku - buku yang berkaitan dengan permasalahan ini dan berbagai sumber - sumber lain yang berasal dari instansi - instansi terkait yaitu kantor BPS Jawa Tengah dan BPS Kabupaten Kendal.

Alat analisis yang digunakan dalam penelitian ini adalah analisis regresi logistik (logistic regression). Alasan penggunaan alat analisis regresi logistik (logistic regression) adalah karena variabel dependen bersifat dikotomi (melakukan pergantian auditor dan tidak melakukan pergantian auditor). Asumsi normal distribution tidak dapat dipenuhi karena variabel bebas merupakan campuran antara variabel kontinyu (metrik) dan kategorial (non-metrik). Dalam hal ini dapat dianalisis dengan regresi logistik (logistic regression) karena tidak perlu asumsi normalitas data pada variabel bebasnya. Dalam peneilitian ini, minat keputusan tenaga kerja menjadi sirkuler bertindak sebagai variabel dependen yang diukur dengan menggunakan angka dummy. Bernilai 0 apabila seseorang bermigrasi sirkuler menetap dengan alasan punya rumah sendiri, bernilai 1 apabila seseorang bermigrasi sirkuler tidak menetap karena sewa kos/ kontrak. Sedangkan variabel independennya adalah Jenis kelamin menggunakan angka dummy dengan $0=$ lakilaki dan $1=$ perempuan. Usia dalam hal ini adalah, usia tenaga kerja yang berasal dari Kab. Kendal yang menjadi migrasi sirkuler di Kota Semarang. Status perkawinan yang dimiliki oleh responden diukur menggunakan angka dummy, yaitu akan bernilai 0 apabila responden belum menikah dan bernilai 1 apabila responden sudah menikah. Tingkat pendidikan dalam penelitian ini adalah jenjang pendidikan terakhir responden yang diperoleh melalui pendidikan formal, baik di sekolah negeri maupun swasta, atau sekolah yang sederajat yang diakui pemerintah, baik mendapat ijazah maupun yang tidak mendapat ijazah. Pendapatan dihitung dari selisih pendapatan antara di desa dan di kota yang diukur dengan rupiah per bulannya, apabila semakin besar selisihnya maka semakin besar keputusan responden untuk migrasi ke kota.

Persamaan model logit pada penelitian ini adalah:

$\operatorname{Ln} \frac{p}{1-p}=\beta 1 \mathrm{X} 1+\beta 2 \mathrm{X} 2+\beta 3 \mathrm{X} 3+\beta 4 \mathrm{X} 4+\beta 5$

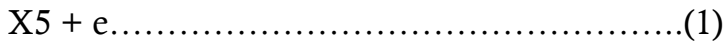

Keterangan :

$\begin{array}{ll}\operatorname{Ln} \frac{p}{1-p} & =\text { Migrasi Sirkuler } \\ \mathrm{X} 1 & =\text { Jenis kelamin } \\ \mathrm{X} 2 & =\text { Usia } \\ \mathrm{X} 3 & =\text { Status Perkawinan }\end{array}$




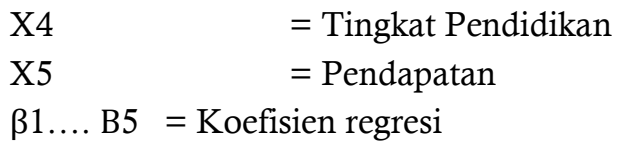

\section{HASIL DAN PEMBAHASAN}

\section{Karakteristik Responden}

Berdasarkan hasil olah data, diketahui bahwa kelompok responden terbesar adalah mereka yang jenis kelamin perempuan yaitu 48 orang sedangkan laki-laki 44 0rang. Sedangkan Kelompok usia kategori terbesar dengan rataan umur 21-29 yaitu mencapai 35 orang sedangkan kelompok umur sirkluer terendah yaitu di atas 50 dengan 1 orang. Dilihat dari status pernikahan, diketahui 47 responden dalam status sudah menikah dan 45 responden dalam status belum menikah. Sebagian besar dalam status menikah, karena itu motivasi keinginan untuk mendapatkan pendapatan yang lebih tinggi semakin besar demi mencukupi kebutuhan keluarga. Dilihat dari tingkat pendidikan, diketahui bahwa sebagian besar responden yang berpendidikan SMA sederajat, sebesar 68 orang. responden berpendidikan D3 atau S1 yaitu sebesar 19 orang. Selanjutnya responden yang hanya mengenyam pendidikan SMP 3 orang dan pasca sarjan 2 orang. Kelompok responden terbesar yaitu mereka yang menerima pendapatan antara 1.500.0001.999.999, yaitu sebesar 41 orang, kemudian responden yang berpendapatan terendah yaitu $<1.000 .000$ sebesar 1 orang. Sedangkan kelompok responden yang berpendapatan tertinggi yaitu $>3.000 .000$ sebesar 8 orang.

\section{Hasil Analisis Binary Logistic Regression Uji Kelayakan Model (Goodness of Fit)}

Nilai signifikansi Hosmer and LemeshowGoodness of Fit Test statistic sebesar 0,599 lebih besar dari of Fit Test statistic $(0,05)$, berarti tidak ada perbedaan signifikan antara model dengan nilai observasinya sehingga model Goodnes Fit sehingga model dapat memprediksi nilai observasinya atau dapat dikatakan model dapat diterima karena cocok dengan data observasinya.

\section{Uji Overall Model Fit}

Dari hipotesis ini jelas bahwa kita tidak akan menolak hipotesis nol agar model fit dengan data. Statistik yang digunakan berdasarkan pada fungsi likelihood. Likelihood L dari model adalah probabilitas bahwa model yang dihipotesiskan menggambarkan data input. Untuk menguji hipotesis nol dan alternatif, L ditransformasikan menjadi -2LogL. Penurunan likelihood (-2LL) menunjukkan model regresi yang lebih baik atau dengan kata lain model yang dihipotesiskan fit dengan data.dapat disimpulkan bahwa nilai log likehood sebesar 55,355 (>1) maka menunjukkan bahwa model baik dan mengindikasikan menaikan nilai $\log$ likehood.

\section{Uji Koefisien Determinasi (Nagelkerke $\mathbf{R}$ Square)}

Nilai Nagelkerke's R2 dapat diinterpretasikan seperti nilai R2 pada multiple regression. Nilai yang kecil berarti kemampuan variabel-variabel independen dalam menjelaskan variasi variabel dependen terbatas. Nilai yang mendekati satu berarti variabel-variabel independen memberikan hampir semua informasi yang dibutuhkan untuk memprediksi variasi variabel dependen.

Disimpulkan bahwa nilai Nagelkerke $R$ Squarenya sebesar $0,667(66,7 \%)$ hal ini berarti bahwa variabel independen dalam penelitian ini hanya mampu menjelaskan tentang variabel dependen sebesar $66,7 \%$ sedangkan sisanya $33,3 \%$ dijelaskan oleh variabel independen di luar variabel dalam penelitian ini.

\section{Uji Parsial}

Dari hasil regresi dengan model Binary Logistic Regression dengan alat analisi SPSS 19 di peroleh hasil sebagai berikut: 
Tabel 4. Variables in the Equation

\begin{tabular}{lllll}
\hline Variabel & B & Wald & Sig & Exp \\
\hline X1 & 1.730 & 4.713 & .030 & 5.639 \\
X2 & .422 & .770 & .380 & 1.526 \\
X3 & -1.346 & 2.267 & .132 & .260 \\
X4 & 5.566 & 16.174 & .000 & 261.377 \\
X5 & -2.611 & 18.733 & .000 & .073 \\
Constant & -13.449 & 9.115 & .003 & .000 \\
\hline
\end{tabular}

a. Variable(s) entered on step 1: X1, X2, X3, X4, X5.

Dari hasil pengolahan data yang dijelaskan dalam Tabel 1.4 dapat dijabarkan dengan rumus persamaan regresi logistic sebagai berikut :

$$
\begin{gathered}
\operatorname{Ln}\left(\begin{array}{c}
P \\
1-p
\end{array}\right)=-13.449+1,730 \mathrm{X} 1+0,422 \mathrm{X} 2 \\
-1,346 \mathrm{X} 3+5,566 \mathrm{X} 4-2,611 \mathrm{X} 5
\end{gathered}
$$

Parameter yang digunakan untuk uji parsial penelitian ini adalah dengan membandingkan antara nilai signifikansi dengan taraf nyata $5 \%$.

\section{Pengaruh Variabel Jenis Kelamin Terhadap Keputusan Seseorang Menjadi Migrasi Sirkuler}

Nilai signfikansi uji hipotesis menggunakan regresi logistik antara jenis kelamin berpengaruh positif dan signifikan terhadap migrasi sirkuler dalam penelitian ini sebesar 0,030 $(<0,05)$ yang berarti bahwa jenis kelamin berpengaruh positif dan signifikan terhadap migrasi sirkuler baik untuk menetap maupun tidak menetap. Orang yang berjenis kelamin laki-laki lebih berkecenderungan untuk melakukan migrasi sirkuler.

Hasil penelitian ini didukung oleh hasil penelitian yang dilakukan oleh Kusumaningrum (2014) menunjukkan bahwa jenis kelamin berpengaruh terhadap commuter.

Tenaga kerja yang memutuskan untuk bermigrasi dari daerah asal ke kota Semarang tidak melihat jenis kelaminnya namun keputusan itu didasarkan dari keinginan dan kemauan untuk meningkatkan taraf hidupnya di masa depan. Sehingga pemerintah perlu untuk menambah lapangan pekerjaan baru di desa sehingga menarik migran untuk tidak pindah dari daerah asal.

\section{Pengaruh Variabel Usia terhadap keputusan seseorang menjadi migrasi sirkuler}

Nilai signfikansi uji hipotesis menggunakan regresi logistik pengaruh antara usia dengan keputusan migrasi sirkuler dalam penelitian ini sebesar $0,380(>0,05)$ yang berarti bahwa usia berpengaruh positif dan tidak signfikan terhadap migrasi sirkuler baik untuk menetap maupun tidak menetap. Tinggi rendahnya usia tidak memiliki pengaruh terhadap keputusan tenaga kerja melakukan migrasi sirkuler.

Hasil hipotesis ini mempunyai arti bahwa secara rata-rata responden berusia 30-39 tahun yang melakukan migrasi sirkuler tidak menetap di Kota Semarang. Akan tetapi setelah dilakukan analisis data dengan menggunakan regresi logistik yang melibatkan variabel independen lain dalam penelitian ini tenaga kerja yang berusia 21-29 tahun yang lebih memutuskan untuk migrasi sirkuler tidak menetap ke kota Semarang.

Hasil penelitian ini didukung oleh hasil penelitian yang dilakukan oleh Kusumaningrum (2014) tentang pengaruh kondisi individu dan sosial - ekonomi terhadap keputusan menjadi commuter ke kota Jakarta (studi pada tenaga kerja sektor formal dari bogor dan depok yang menggunakan kereta commuter line) yang menunjukkan bahwa usia tidak berpengaruh terhadap commuter. 
Pengaruh status perkawinan terhadap keputusan seseorang menjadi migrasi sirkuler Nilai signfikansi uji hipotesis menggunakan regresi logistik antara status perkawinan terhadap keputusan migrasi sirkuler dalam penelitian ini sebesar $0,132(>0,05)$ yang berarti bahwa status perkawinan berpengaruh negatif dan tidak signifikan terhadap keputusan migrasi sirkuler baik untuk menetap maupun tidak menetap. Perbedaan status perkawinan responden tidak mempengaruhi keputusan migrasi sirkuler.

Hasil hipotesis ini mempunyai arti bahwa secara rata-rata responden status perkawinan sudah menikah yang melakukan migrasi sirkuler tidak menetap di Kota Semarang. Akan tetapi setelah dilakukan analisis data dengan menggunakan regresi logistik yang melibatkan variabel independen lain dalam penelitian ini tenaga kerja yang belum menikah yang lebih memutuskan untuk migrasi sirkuler tidak menetap ke kota Semarang.

Hasil penelitian ini didukung oleh hasil penelitian yang dilakukan oleh Pangaribuan (2013) tentang Analisis Pengaruh Pendapatan, Pendidikan, Pekerjaan Daerah Asal, Jumlah Tanggungan Dan Status Perkawinan Terhadap Keputusan Migrasi Sirkuler Ke Kota Semarang (Studi Kasus: Kecamatan Tembalang Dan Pedurungan) menunjukkan bahwa status perkawinan tidak berpengaruh terhadap migrasi.

Untuk Status perkawinan yang sudah menikah yang disandang oleh tenaga kerja semakin memotivasi tenaga kerja untuk bermigrasi ke kota Semarang. Status pernikahan ini akan membuat beban hidup responden bertambah sehingga mendorong mereka untuk meninggalkan daerah asal dan beralih pada daerah lain jika ada perbedaan pendapatan di daerah lain. Oleh karena itu pemerintah perlu meningkatkan program penyuluhan $\mathrm{KB}$ bagi penduduk sehingga dapat membuat pernikahan mereka lebih terencana. Dengan demikian minat penduduk untuk melakukan migrasi sirkuler dapat terkontrol pula.

Pengaruh variabel tingkat pendidikan terhadap keputusan seseorang menjadi sirkuler
Nilai signfikansi uji hipotesis menggunakan regresi logistik antara tingkat pendidikan berpengaruh positif dan signifikan terhadap migrasi sirkuler dalam penelitian ini sebesar $0,000(<0,05)$ yang berarti bahwa tingkat pendidikan berpengaruh positif dan signifikan terhadap migrasi sirkuler baik untuk menetap maupun tidak menetap. Semakin tinggi tingkat pendidikan akan mempengaruhi migrasi sirkuler dengan tujuan untuk menetap karena mempunyai rumah sendiri.

Secara rata-rata responden mempunyai tingkat pendidikan dasar dan atas yang melakukan migrasi sirkuler tidak menetap di Kota Semarang. Dimana setelah dilakukan analisis data dengan menggunakan regresi logistik yang melibatkan variabel independen lain dalam penelitian ini tenaga kerja yang mempunyai tingkat pendidikan dasar dan atas yang lebih memutuskan untuk migrasi sirkuler tidak menetap ke kota Semarang.

Hasil penelitian ini didukung oleh hasil penelitian yang dilakukan oleh Rizal (2006) dan Pangaribuan (2013) tentang keputusan migrasi sirkuler pekerja sektor formal di Kota Medan menunjukkan bahwa pendidikan berpengaruh terhadap migrasi sirkuler.

Semakin tinggi tingkat pendidikan masyarakat, akan semakin kuat keinginan memperoleh pekerjaan yang lebih baik di kota daripada di desa. Hendaknya pemerintah dan instansi-instansi yang terkait memberikan sosialisasi pemberdayaan UKM di desa, serta mengajak masyarakat khususnya yang berpendidikan tinggi untuk dapat berpartisipasi dalam pembangunan desa. Mereka dapat mendirikan UKM dan dapat menciptakan lapangan pekerjaan baru untuk penduduk desa, sehingga dapat mengurangi kepadatan kota.

\section{Pengaruh pendapatan terhadap keputusan seseorang menjadi migrasi sirkuler}

Nilai signfikansi uji hipotesis menggunakan regresi logistik antara pendapatan terhadap keputusan migrasi sirkuler dalam penelitian ini sebesar $0,000(<0,05)$ yang berarti bahwa pendapatan berpengaruh negatif dan signifikan terhadap keputusan migrasi sirkuler 
baik untuk menetap maupun tidak menetap. Artinya Seseorang yang memiliki pendapatan tinggi tidak akan melakukan migrasi sirkuler dengan tujuan menetap dan sebaliknya seseorang dengan pendapatan rendah akan melakukan migrasi sirkuler dengan tujuan untuk tidak menetap.

Hasil penelitian ini tidak didukung oleh hasil penelitian yang dilakukan oleh Pangaribuan (2013) dan Agrista (2015) yang menunjukkan bahwa pendapatan berpengaruh terhadap migrasi sirkuler.

Hasil penelitian ini didukung oleh hasil penelitian yang dilakukan oleh Kusumaningrum (2014) tentang pengaruh kondisi individu dan sosial - ekonomi terhadap keputusan menjadi commuter ke kota Jakarta (studi pada tenaga kerja sektor formal dari bogor dan depok yang menggunakan kereta commuter line) yang menunjukkan bahwa pendapatan berpengaruh terhadap commuter.

Agar tidak banyak terjadi migrasi sirkuler lebih banyak oleh karena itu pemerintah perlu mengembangkan potensi di berbagai daerah supaya kesejahteraan masyarakat juga dapat meningkat, karena hampir semua responden mengatakan bahwa faktor pendapatan di daerah tujuan lebih besar sehingga membuat mereka berpikir untuk bekerja di luar daerah asal dengan harapan mendapat pendapatan yang lebih tinggi.

\section{SIMPULAN}

Berdasarkan pembahasan diatas maka simpulan dalam penelitian ini adalah (1) Jenis kelamin berpengaruh positif dan signifikan terhadap migrasi sirkuler, (2) Usia berpengaruh positif dan tidak signifikan terhadap migrasi sirkuler, (3) Status perkawinan berpengaruh negatif dan tidak signifikan terhadap migrasi sirkuler, (4) Tingkat pendidikan berpengaruh positif dan signifikan terhadap migrasi sirkuler, (5) Pendapatan berpengaruh negatif dan signifikan terhadap migrasi sirkuler.

Saran yang dapat diberikan adalah pemerintah daerah sebagai pemegang kebijakan harus benar-benar peduli dalam penyediaan lapangan pekerjaan bagi warga setempat agar warga setempat tidak perlu bermigrasi untuk mencari pekerjaan.

\section{DAFTAR PUSTAKA}

Agrista, Zeko, 2015. Mobilitas Sirkuler Penduduk Pulau Pisang Ke Kota Krui Tahun 2013.

Boncea, Irina. 2015. Brain Drain or Circular Migration: The Case of Romanian Physicians. Procedia Economics and Finance, 32, pp.649-656.

BPS Kabupaten Kendal dalam Angka Tahun 2014

Disnakertrans jateng 2014. "Perbandingan UMK Kota Semarang dan Kabupaten Kendal".

Erviyana, P., \& Pujiati, A.. Analisis Persistensi Inflasi Jawa Tengah. Economics Development Analysis Journal, 4(1).

$\mathrm{Hu}$, Feng. 2011. Circular migration, or permanent stay? Evidence from China's ruralurban migration. China Economic Review, 22(1), pp.64-74.

Imam Ghozali, 2011, Aplikasi Analisis Multivariate dengan Program SPSS, BP UNDIP, Semarang

Kusumaningrum, Syifa Putri. 2014, Pengaruh Kondisi Individu Dan Sosial - Ekonomi Terhadap Keputusan Menjadi Commuter Ke Kota Jakarta (Studi pada Tenaga Kerja Sektor Formal dari Bogor dan Depok yang Menggunakan Kereta Commuter Line). Jurnal Ilmiah Ilmu Ekonomi Universitas Brawijaya. Vol 1(3).

Lee, E.S, 1992, Teori Migrasi (terjemahan), Pusat Penelitian Kependudukan Universitas Gadjah Mada, Yogyakarta

Mantra, Ida Bagoes, 1992, Mobilitas Penduduk Sirkuler Dari Desa ke Kota di Indonesia, Pusat Penelitian Kependudukan, Universitas Gadjah Mada, Yogyakarta

Pangaribuan, Kaisar Hasudungan. 2013, Analisis Pengaruh Pendapatan, Pendidikan, Pekerjaan Daerah Asal, Jumlah Tanggungan dan Status Perkawinan Terhadap Keputusan Migrasi Sirkuler Ke Kota Semarang (Studi Kasus: Kecamatan Tembalang Dan Pedurungan) Skripsi S1. FE UNDIP: Semarang.

Qin, Fei. 2015. Global talent, local careers: Circular migration of top Indian engineers and professionals. Research Policy, 44(2), pp.405-420.

Rizal, Muhammad, 2006. Keputusan Migrasi Sirkuler Pekerja Sektor $\quad$ Formal Di Kota Medan. Skripsi S1. FE 
Hastu Rahma Anggraini dan Fafurida / Economics Development Analysis Journal 5 (4) (2016)

Todaro, M.P, 2000, Pembangunan Ekonomi di Dunia Ketiga, diterjemahkan oleh Haris Munandar, Erlangga, Jakarta

Uma Sekaran, 2006, Metodologi Penelitian untuk Bisnis, Edisi 4, Buku 1, Jakarta: Salemba Empat. 